\title{
THE BOND STRENGTH OF STEEL BAR BASE ON RIB GEOMETRY BAR IN PULLOUT TEST
}

\author{
Anis Rosyidah ${ }^{1,2}$, Johannes Adhijoso Tjondro ${ }^{2}$ and I Ketut Sucita ${ }^{1}$
}

1. Politeknik Negeri Jakarta, Department of Civil Engineering, Jl. Prof. GA. Siwabessy Kampus UI Depok,16425, Indonesia; anis.rosyidah@sipil.pnj.ac.id; i.ketutsucita@sipil.pnj.ac.id

2. Universitas Katolik Parahyangan Bandung, Department of Civil Engineering, Jl. Ciumbuleuit No.94, Bandung, 40141, Indonesia; jatjondro@yahoo.com

\begin{abstract}
This experiment's objective is to prove that the reinforcing rib's form contributes to its bond strength. The specimen is the concrete cubes measuring $150 \times 150 \times 150 \mathrm{~mm}$; bar installed in the center of the concrete cube. Bars use 13, 16, and $19 \mathrm{~mm}$ diameters. For comparison, the experiment was also carried out on plain reinforcement diameter with $12 \mathrm{~mm}, 16 \mathrm{~mm}$, and $19 \mathrm{~mm}$. Concrete compression is $\mathrm{fc}^{\prime} 34 \mathrm{MPa}$. The pullout test was also performed to increase the load in stages at a $200 \mathrm{~kg} /$ minute speed. Loading stopped if the reinforcement yielded, split concrete, or slipped bar. The experiment uses ASTM standards ASTM C234-91a. The study results are the bond strength on reinforcement with the surrounding concrete. Bond strength in the plain bar is lower than deformed. The reinforcement of steep rib compared to fishbone bond strength values incline to be the same. The ratio of the bond strength of plain compared to deformed is $15 \%-18 \%$. The bond index of the steep rib and fishbone rib between $0.11-0.16$ so that the bond stress obtained is also relatively the same. The failure pattern that occurs is determined based on the bond stress-slip graph. There are two types of collapse in this experiment, namely pullout and splitting damage. The failure of each specimen based on the diameter and shape of the rib varies greatly. The splitting damage is seen visually only in the specimen of the D19 fishbone rib.
\end{abstract}

\section{KEYWORDS}

Bond-behavior, Relative rib area, Tensile test, Deformed bar

\section{INTRODUCTION}

Concrete is a structural material that is commonly used both for building structures and bridge structures. The nature of concrete that is resistant to fire, durable, easily formed, easy to form, and available building material; makes one reason for the use of concrete materials is still high. The type of concrete used in the structure is reinforced concrete, a composite material consisting of reinforced concrete and steel, which synergizes carrying the forces at work. Concrete can withstand the compressive force, and steel reinforcement withstands the tensile force. Steel material is straightforward to obtain, so it is still a favorite construction material.

The strength of reinforced concrete is also determined based on the interaction between reinforcement and concrete. Force transfer can work well if there is a perfect bond between the reinforcement and concrete surfaces [1]. This bond is appropriately formed when the rough reinforcement's surface so that in structural reinforced concrete using deform reinforcing.

There are currently enough factories that produce steel bars with various ribs; there are ribs that form angles, and some are perpendicular to the longitudinal groove. It is called bamboo ribs. The steep ribs are angles that form angles but the ribs' tips so that they do not converge the 
reinforcement's longitudinal grooves. For fishbone is the ribs form an angle; the edges thick into the longitudinal grooves of reinforcement. They are commonly used as reinforced concrete material in the construction world.

It delivers a good bond between reinforcement and concrete. Guohua Xing et al. (2015) research results that the plain bar's bond strength is only $18.3 \%$ of the deform bar; thus, the deform bar's bond strength is better than the plain bar [2]. This result supports the earlier research conducted by Feldmen (2005) [3]. The contribution of bond strength values to the plain reinforcement is determined by the friction and adhesion forces. In contrast, the deform bar and the friction and adhesion forces are also determined by the interlocking force [2]. The interlocking force comes from the unevenness of the reinforcement surface.

Different shapes of deformed reinforcement steel ribs may contribute to different interlocking values, resulting in different bond stress. In SNI 2847-2019 [4], the determining factors of reinforcement development length are jointing point, coating of reinforcement steel, the diameter of reinforcement, and type of aggregate concrete used, whereas the rib shape is not included. Research on bond strength between deformed reinforcement steel and concrete by considering various rib shapes is necessary to prove that rib shape contributes to the bond stress [5], [6]. The test used to obtain bond stress is a direct pullout test. Following, in this paper, the strength of concrete reinforcement in concrete is discussed. The review's focus is the contribution of the shape of the thread reinforcement to its bond strength.

The previous research concerning the study of bond strength has been carried out, among others: et al. (2015) evaluates the bond strength of plain reinforcement in concrete compared to the deform bar [2]. Research parameters include reinforcement length embedded in concrete, reinforcement surface type, and bar diameter. The experiment behavior of plain and deform bar attachment in concrete showed only about $18.2 \%$ of reinforcing the reinforcing deform. In addition to friction and adhesion forces, the degree of the value of bond strength on the reinforcement is due to interlocking the reinforcement surface. [2]. The pullout experiment by Feldman \& Bartlett (2005), plain bar embedded to concrete by reviewing various parameters including concrete compressive strength, reinforcement size, reinforcement shape, concrete blanket, and reinforcement surface roughness. The results obtained include, the maximum tensile load occurs at a minimal slip $(\sim 0.01 \mathrm{~mm})$, the load then drops asymptotically to the residual value when the slip increases to $10 \mathrm{~mm}$. The slip-load curve can be represented with a load as a linear function of the slip logarithm. The average reinforcement strength is $0.98 \mathrm{MPa}$ and increased by $124 \%$ to 2.2 MPa for the deform bar [3].

The bond strength and the mechanism of collapse in the deform bar can be predicted with the bearing angle model (BAM); the failure of attachment to the deform bar can be caused by splitting. The split and shear collapse occurs to achieve ultimate strength; it needs to be restrained using stirrup bars [7]. Researched bond reinforcement whose ribs were generated using a machine to decrease the thread height, the bond stress obtained from the reinforcement bar [8].

Other research related to bond strength is Feng $\mathrm{Xu}$ et al. (2014) research on plain reinforcement with uniaxial and lateral biaxial loads [9]. Ultimate bond strength increases with the addition of lateral force. The size of the bar and compressive strength of concrete does not significantly influence the increase in bond strength [10]. Sungnam Hong and Sun-Kyu Park (2012) studied the relationship between bond-slip stress in reinforced concrete due to axial tensile loads [11]. Feng Lan Li et al. (2013) conducted a study of the strength of plain reinforcement with MSC (Made-Sand Concrete) [12]. Hyo-Gyoung Kwak \& Jin-Kook Kim (2006) implemented the bond-slip effect on reinforced concrete portals with cyclic loads; the results obtained that the portal decreased stiffness due to failure bond-slip [13]. In 2010, Hyo-Gyoung Kwak \& Jin-Wook Hwang investigated models with numerical simulations of bond-slip on reinforced concrete bridge girders. The force balance equation, the curvature distribution, and the bending moment linear distribution are influenced by slip behavior. It turned out that the results of numerical simulations with experiments obtained the same results [14]. 


\section{Bond strength}

Many complex factors affect bond strength. However, three factors are crucial: adhesion, friction, and interlocking force [2]. The determining factors of bond strength for plain reinforcement steel are adhesion and friction of contacting surfaces of reinforcement steel and concrete around it. During the outset loading, the reinforcement undergoes a slip, but adhesive interaction withstands it. As the load becomes heavier to withstand, friction force works [15], [16]. On deformed reinforcement steel, in addition to adhesion and friction, there is the interlocking force that occurs between the reinforcement and concrete. This force provides a greater bondability for deformed reinforcement steel than plain reinforcement steel [2].

The pattern of bond stress between reinforcement and concrete can be predicted using a direct pullout test. Furthermore, the test results are analyzed and represented in the bond stressslip relationship graph, as presented in Figure 1 [11], [17].

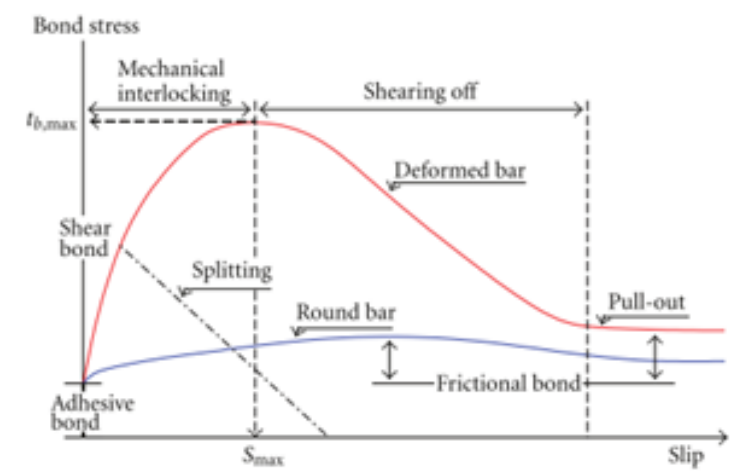

Fig. 1 - Bond Stress - Slip Relationship Graph [11], [17]

Figure 1 demonstrates the slip mechanism for bond stress of plain and deformed reinforcement steel. The bond stress value of plain reinforcement steel is lesser than deformed reinforcement steel. On plain reinforcement steel, adhesion occurs when the load is still relatively small, and the slip has not occurred, then friction withstands the more significant load [11], [17], [18]. On deformed reinforcement steel, adhesion also occurs when the load is still small, then friction and interlocking work. If the splitting failure occurs, peak stress has not been reached yet and then decreased [18]. Pullout failure occurs if the bond stress has reached a maximum value, decreases, and tends to be constant at a certain point [11], [17].

The bond stress value of the pullout test can be counted as the average bond stress value if the length of reinforcement planting is $5 \mathrm{D}$ (5 times the diameter of reinforcement steel) at maximum [19], [20]. 5D length is categorized in little anchorage with equal bond stress through the length of the reinforcement planted inside the concrete. The equation of average surface bond stress through the length of the reinforcement planted inside the concrete is presented in equation (1).

$$
\tau=P /(\pi D L)
$$

in which $\mathrm{P}=$ pullout force, $\mathrm{D}=$ diameter of bar, $\mathrm{L}=$ length of bar embedded inside the concrete.

\section{Bond mechanism}

The bond mechanism between reinforcement and concrete is affected by several parameters, such as the reinforcement surface's roughness and the reinforcement rib's shape. The geometric shape of reinforcement, especially rib, contributes significantly to its bond strength. The relationship between rib shape and bond strength is a bond index or relative rib area (fR). The 
bond index is a ratio of the rib area to the area of reinforcement between ribs [11], [18], [21], [22]. There is an increase in the bond strength up to $40 \%$ with a bond index ranging from 0.04 to 0.10 that is caused by the interaction between concrete and reinforcement rib, which reduces the risk of splitting failure [21]. The equation of the bond index (fR) presented in eq. (2).

$$
f_{R}=\pi\left(d_{e}^{2}-d_{i}^{2}\right) /\left(4 d S_{r}\right)
$$

in which $f_{R}=$ bond index or relative rib area, $d_{e}=$ outer diameter of reinforcement, $d_{i}=$ inner diameter of reinforcement, $d=$ nominal diameter of reinforcement, $S_{r}=$ space between ribs from axis to axis.

\section{METHODS}

The test material used was deformed reinforcement steel cast monolithically with cuboid concrete with a size of $150 \mathrm{~mm} \times 150 \mathrm{~mm} \times 150 \mathrm{~mm}$ [9]. The contact area between reinforcement and concrete was as long as 5D, as shown in Figure 2 [23], [24]. The concrete quality used was fc' $34 \mathrm{MPa}$. The deformed reinforcement steel consisted of TGS (Toyogiri Iron Steel) brand, fishbone rib reinforcement steel, and KS (Krakatau Steel) brand steep rib reinforcement (Figure 3) with diameters of D13 mm, D16 mm, and D19 mm. The test results of those two types of deformed reinforcement steel were then compared with a bond strength of plain reinforcement steel with diameters approximately equal, namely D12, D16, and D19. A spiral stirrup was installed to anticipate crack and an increase of shear strength [25].

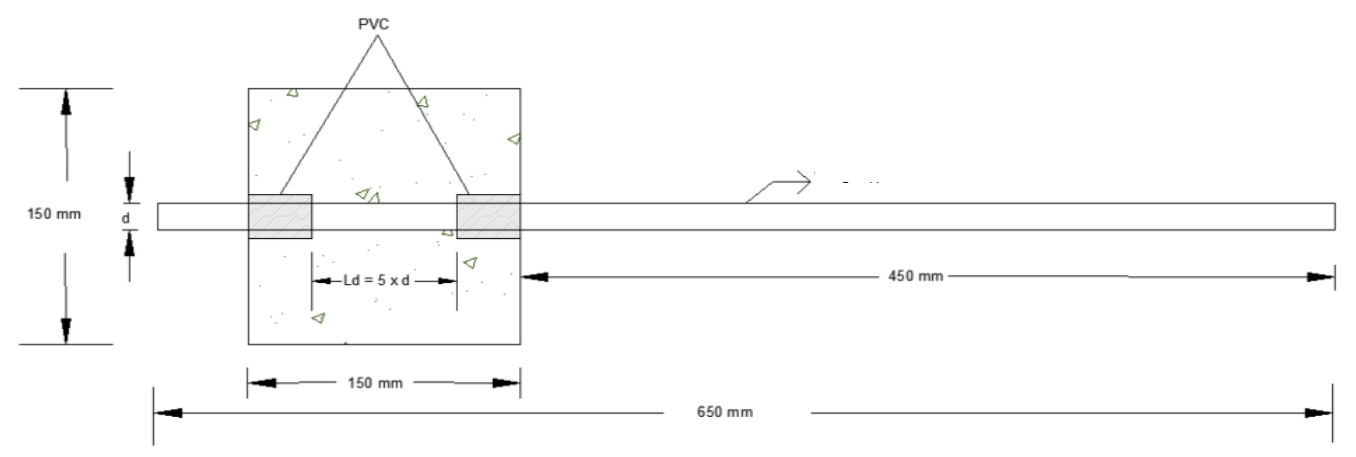

Fig. 2 - The shape of specimen for pullout test [17], [26]

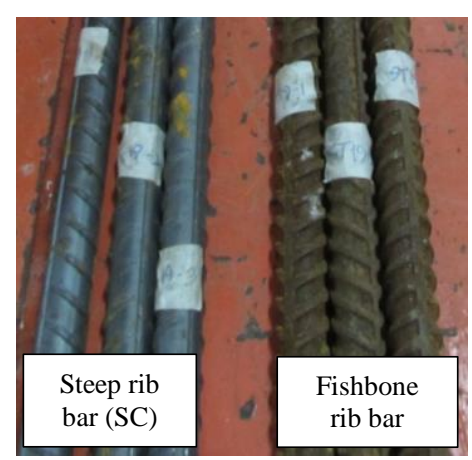

Fig. 3 - The pattern of rib bar

In this experiment, one strain gauge installed on the specimen, in this case, is the steel bar. The specimens used in this study were 27 samples, with details shown in Table 1 - each bar diameter made in 3 times. There was not $13 \mathrm{~mm}$ diameter plain reinforcement available in the market; thus, reinforcement with approximately equal diameter available, in this case, $12 \mathrm{~mm}$, was used. 


\section{$\prod_{\text {ENGINEERING }}$ \\ ENGINEERING}

Article no. 13

THE CIVIL ENGINEERING JOURNAL 1-2021

Tab. 1 - Research Samples

\begin{tabular}{|c|c|c|}
\hline Steel Bar Type & Diameter $(\mathbf{m m})$ & Quantity (pcs) \\
\hline \multirow{3}{*}{ Steep rib bar (SC) } & $\mathrm{D} 13$ & 3 \\
\cline { 2 - 3 } & $\mathrm{D} 16$ & 3 \\
\cline { 2 - 3 } & $\mathrm{D} 19$ & 3 \\
\hline \multirow{2}{*}{$\begin{array}{c}\text { Fishbone rib bar } \\
\text { (ST) }\end{array}$} & $\mathrm{D} 13$ & 3 \\
\cline { 2 - 3 } & $\mathrm{D} 16$ & 3 \\
\hline \multirow{3}{*}{ Plain bar (P) } & $\mathrm{D} 19$ & 3 \\
\cline { 2 - 3 } & $\mathrm{D} 12$ & 3 \\
\cline { 2 - 3 } & $\mathrm{D} 16$ & 3 \\
\hline Total & $\mathrm{D} 19$ & 3 \\
\hline & & $\mathbf{2 7}$ \\
\hline
\end{tabular}

The specimens are made using molds; each size $150 \times 150 \times 150 \mathrm{~mm}$ is given a partition, the molds material made from multiplex and wood. The middle of each specimen is given a hole as a reinforcement and PVC pipe, as in Figure 4. The stirrups are installed on this specimen to anticipate cracking and increase its shear strength.

The next stage is the process of casting specimens carried out in the laboratory (Figure 5). The specimen has hardened in about seven days, then opened the mold and carried out maintenance for 28 days to maintain the hydration heat reaction to achieve the concrete quality target.

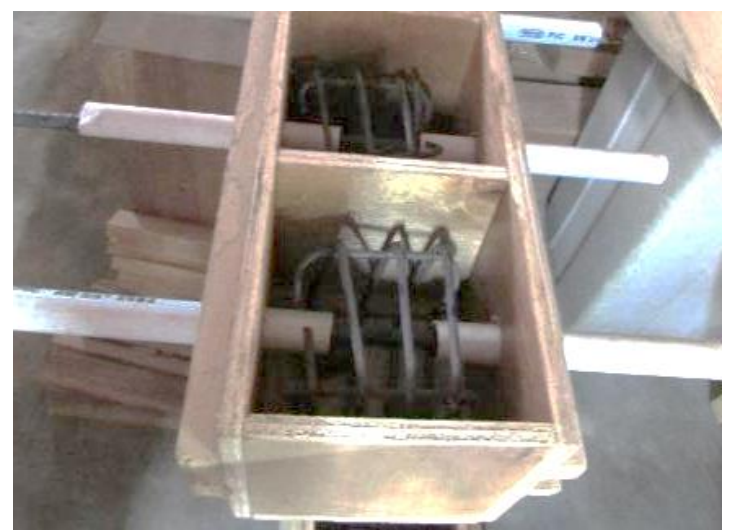

Fig. 4 - Specimen moldings

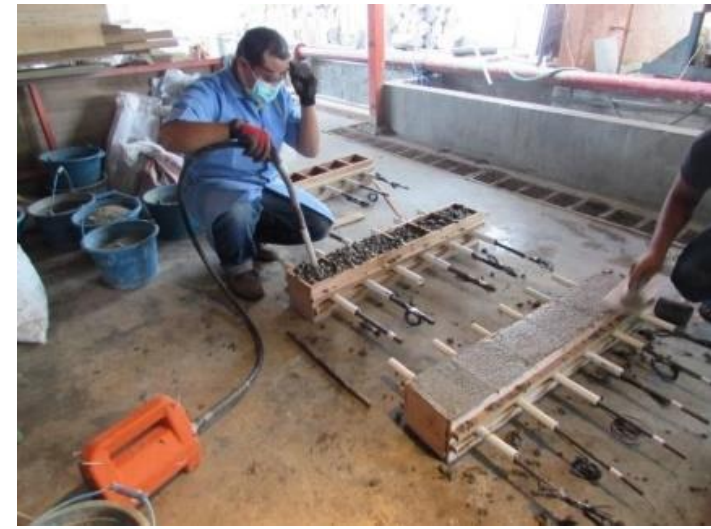

Fig. 5 - Specimen casting

The bar pullout test refers to ASTM 234-91a [27]. The test equipment used was Universal Testing Machine (UTM) with concrete placed on top and reinforcement pulled, as shown in Figure 6 . The specimen was tested more than 28 days old, so the concrete's compressive strength has reached $100 \%$ [28]. A dial gauge was installed on top of the steel bar to detect the total reinforcement slip. Loads added with a maximum speed of $22 \mathrm{kN} /$ minute. Tests carried out until failure encountered on the test materials. 


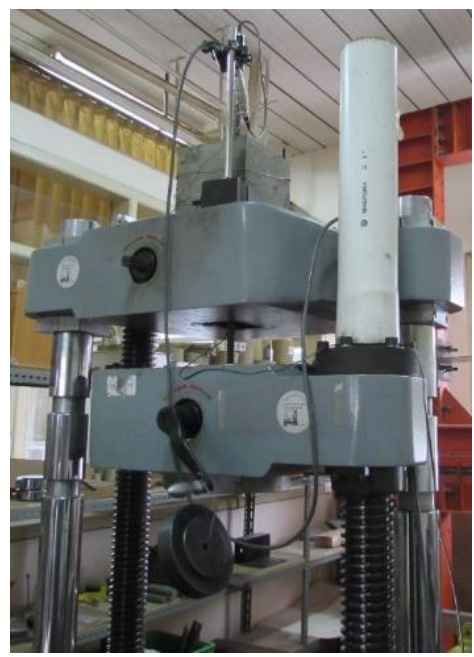

Fig. 6 - Pullout Test Set-Up Using UTM

After the pullout testing had been carried out, the test results in the form of length change and loading history were obtained. The bond index value (eq. 2) of each rib shape was calculated as well. Subsequently, the results were compared with similar research to find the tendency pattern of bond strength and each test material's failure.

\section{RESULTS}

\section{Relative rib area (Bond Index)}

The bond index value of steep type and fishbone type deformed steel bar ranges from 0.11 to 0.13 and from 0.14 to 0.16 , respectively. The bond index value of steep type reinforcement steel is slightly lower than the fishbone type steel bar.

\section{Bond stress - slip curve}

The bond stress-slip curve was used to identify bond capacity between reinforcement and concrete, starting from the smallest load and gradually increasing until failure. Based on prior researches [19], [20]. The bond stress used may be average bond stress if the length of contact area between reinforcement and concrete is 5 (five) times the bar diameter at maximum. Figure 7 shows the result of the $\mathrm{P} 12$ plain reinforcement steel pullout test. Both specimens show differences in the shape of the bond stress-slip curve.

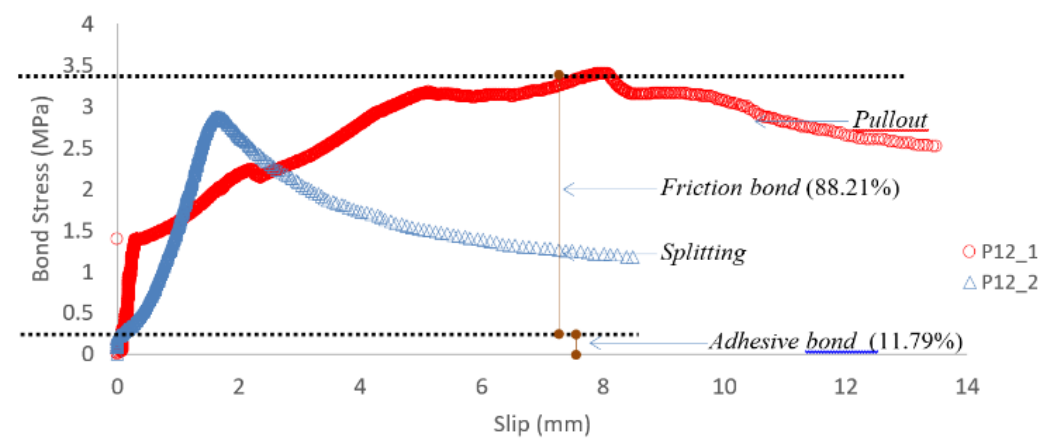

Fig. 7 - Bond Stress - Slip Graph of P12 Plain Reinforcement Steel

The curve consists of two types of bond, namely adhesive bond and friction bond. This result is identical to research conducted by Shima (1987) and Hong \& Park (2012) [11], [17]. The 
adhesive bond is approximately $0.4 \mathrm{MPa}$, reaching $12 \%$, while the friction bond is $88.21 \%$ of the maximum bond stress achieved. These percentages are in line with the result of research conducted by Xing et al. [2], in which the bond strength of plain reinforcement steel is contributed by $11 \%$ adhesive bond and $89 \%$ friction bond. Figure 7 suggests that the maximum bond strain of the P12_1 specimen is $3.4 \mathrm{MPa}$ because it slipped by using $8 \mathrm{~mm}$. Based on the bond stress-slip curve form, the specimen of P12_1 undergoes pullout failure. P12_2 specimen shows a different pattern of the curve from the P12_1 specimen. The bond stress is also lower, less than $3 \mathrm{MPa}$, as it slipped by $1.5 \mathrm{~mm}$. The P12_2 specimen undergoes splitting failure.

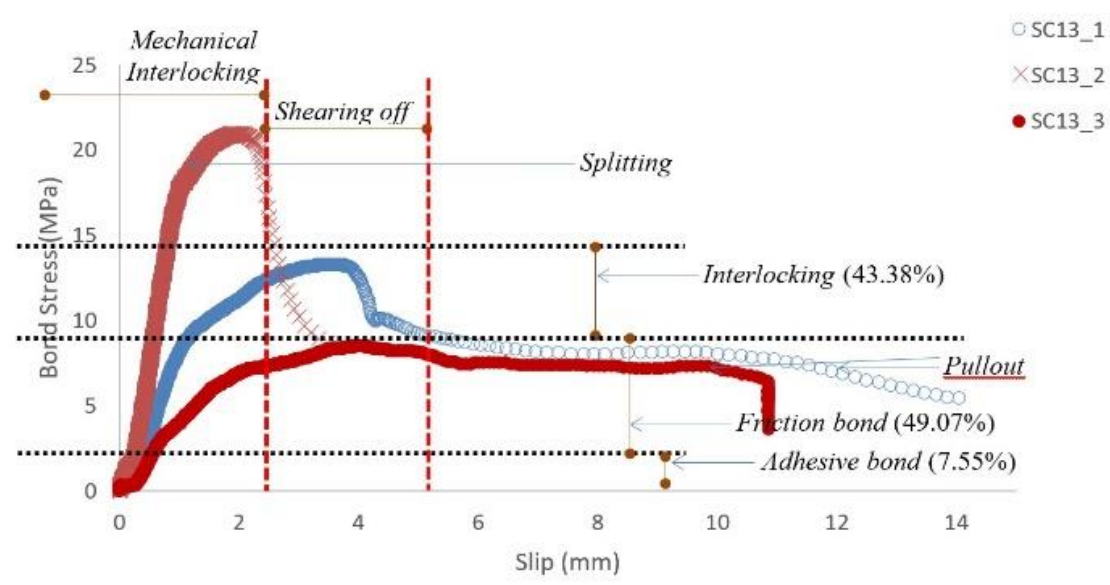

Fig. 8 - Bond Stress - Slip Graph of Steep Type Deformed Reinforcement Steel (SC13)

Figure 8 shows the pullout result; take a look at for SC13 steep type deformed reinforcement steel. Those three specimens indicate variations in the shape of the bond stress-slip curve. Specimens of SC12_1 and SC13_3 denote a similar pattern in the bond stress-slip curve with maximum bond stress reached less than $15 \mathrm{MPa}$ as it slipped by approximately $4 \mathrm{~mm}$. SC13_2 specimen shows more significant bond stress, nearly $20 \mathrm{MPa}$ with a $2 \mathrm{~mm}$ slip. Bond mechanisms that occur on this specimen are an adhesive bond, friction bond, and interlocking with the contribution of $7.55 \%, 49.07 \%$, and $43.38 \%$, respectively. Failure undergone by SC13_1 and SC13_3 specimens is pullout, whereas SC13_2 undergoes splitting failure.

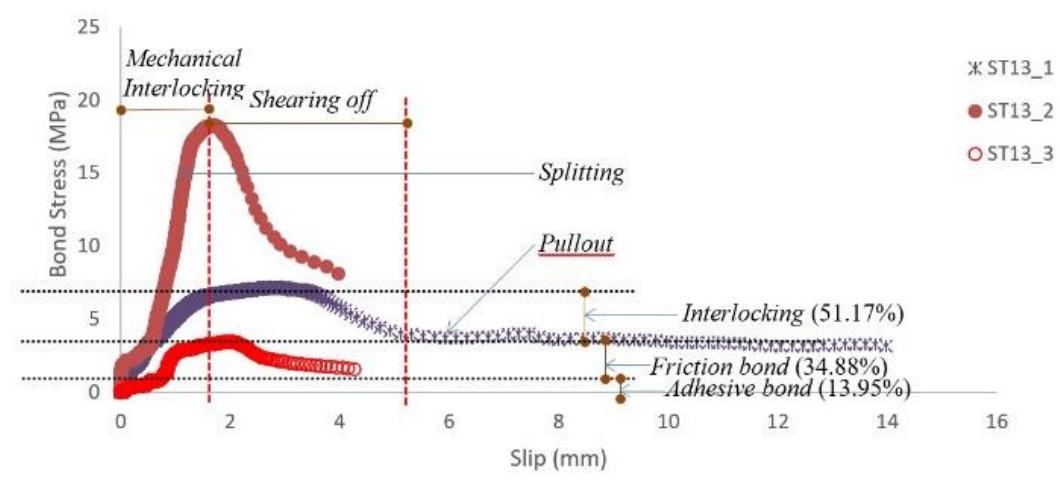

Fig. 9 - Bond Stress - Slip Graph of Fishbone Type Deformed Reinforcement (ST13)

Figure 9 illustrates the result of the pullout test for the ST13 fishbone type deformed reinforcement steel. The three specimens show the different patterns in the bond stress-slip curve. ST13_1 and ST13_3 specimens indicate a similar pattern in the bond stress-slip curve. The maximum bond stress obtained is not higher than $8 \mathrm{MPa}$ with a slip of approximately $3 \mathrm{~mm}$. ST13_2 denotes a higher bond strength, reaching $18 \mathrm{MPa}$ with a $2 \mathrm{~mm}$ slip. Bond mechanisms 
that occur on this specimen are an adhesive bond, friction bond, and interlocking with the contribution of $13.95 \%, 34.88 \%$, and $51.17 \%$, respectively. ST13_1 specimen undergoes pullout failure, whereas ST13_2 undergoes splitting failure.

Test results of 12 \& 13 diameter steel bars with distinct surfaces indicate the bond stress values sequentially from the lowest to the highest: P12 plain reinforcement steel, ST13 fishbone type deformed reinforcement steel, and SC13 steep type deformed reinforcement steel.

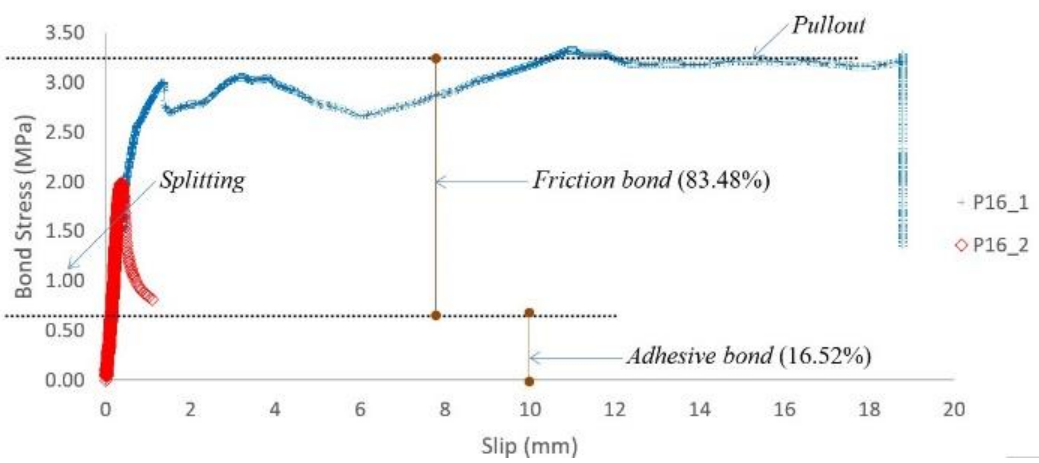

Fig. 10 - Bond Stress - Slip Graph of P16 Plain Reinforcement Steel

Figure 10 shows the result of the pullout test for P16 plain reinforcement steel. Both specimens denote different patterns in the bond stress-slip curve. It indicates that the maximum bond stress of the P16_1 specimen is $3.5 \mathrm{MPa}$ as it slipped by $10 \mathrm{~mm}$. Based on the pattern in the bond stress-slip curve, the P16_1 specimen undergoes pullout failure. P16_2 shows a different curve pattern from P16_1 and lower bond stress, less than $2 \mathrm{MPa}$, as it slipped by $0.5 \mathrm{~mm}$. P16_2 specimen undergoes splitting failure. The bond mechanism of plain reinforcement steel only consists of the adhesive bond and friction bond with a percentage of $16.52 \%$ and $83.48 \%$, respectively.



Fig. 11 - Bond Stress - Slip Graph of Steep Type Deformed Reinforcement Steel (SC16)

Figure 11 shows the result of the pullout test for SC16 steep type reinforcement steel. The three specimens indicate distinct patterns in the bond stress-slip curve. SC16_1 and SC16_3 specimens have an almost identical pattern in the bond stress-slip curve with maximum bond stress reached are $14 \mathrm{MPa}$ with an approximately $4 \mathrm{~mm}$ slip. SC16_2 denotes higher bond stress, reaching $18 \mathrm{MPa}$ with a $2 \mathrm{~mm}$ slip. In this specimen, bonding mechanisms are an adhesive bond, friction bond, and interlocking with a percentage of $7.18 \%, 39.47 \%$, and $53.35 \%$, respectively. Failure undergone by SC16_1 and SC16_3 is pullout, whereas SC16_2 is splitting. This stressstrain diagram has a pattern similar to the results of Wang (2018) [25]. 


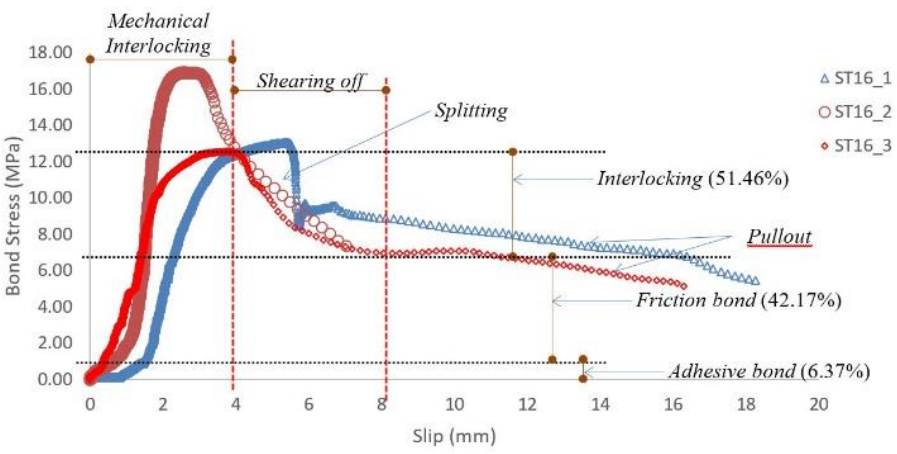

Fig. 12 - Bond Stress - Slip Graph of Fishbone Type Deformed Reinforcement Steel (ST16)

Figure 12 illustrates the result of the pullout test for ST16 fishbone type reinforcement steel. The three specimens indicate similar patterns in the bond stress-slip curve. ST16_1 and ST16_3 specimens show an almost identical pattern in the bond stress-slip curve with maximum bond stress reached is $13 \mathrm{MPa}$ with a slip of approximately $4 \mathrm{~mm}$. ST16_2 denotes higher bond stress, reaching $17 \mathrm{MPa}$ with a slip of approximately $2 \mathrm{~mm}$. In this specimen, bond mechanisms are an adhesive bond, friction bond, and interlocking with a percentage of $6.37 \%, 42.17 \%$, and $51.46 \%$, respectively. Failure undergone by ST16_1 and ST16_3 is pullout, whereas ST16_2 is splitting [25].

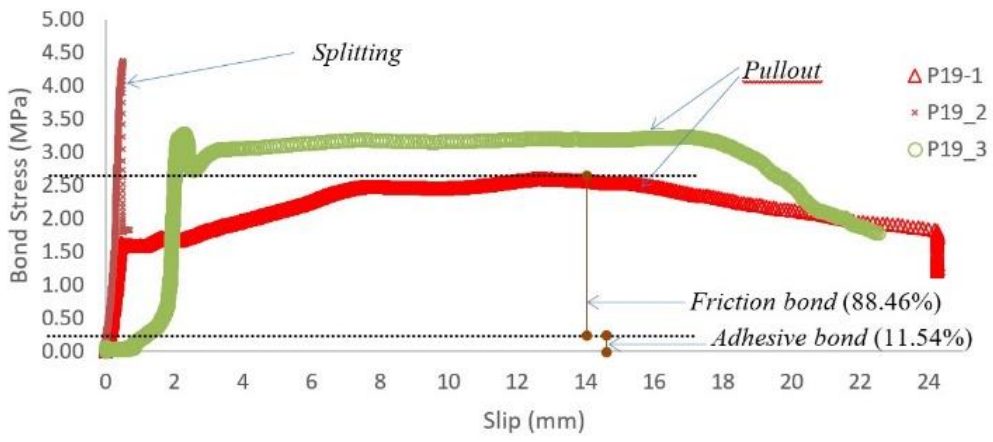

Fig. 13 - Bond Stress - Slip Graph of Plain Reinforcement Steel (P19)

Figure 13 shows that, based on the bond stress-slip curve pattern, the P19_2 specimen undergoes splitting failure. The bond stress value reaches $4.5 \mathrm{MPa}$, but the amount decreases afterward. P19_1 and P19_3 specimens indicate a similar curve pattern with bond stress lower than P19_2, which is less than 3.5 MPa. P19_1 and P19_3 specimens undergo splitting failure as well. The bond mechanism of plain reinforcement steel only consists of the adhesive bond and friction bond with a percentage of $11.54 \%$ and $88.46 \%$, respectively.

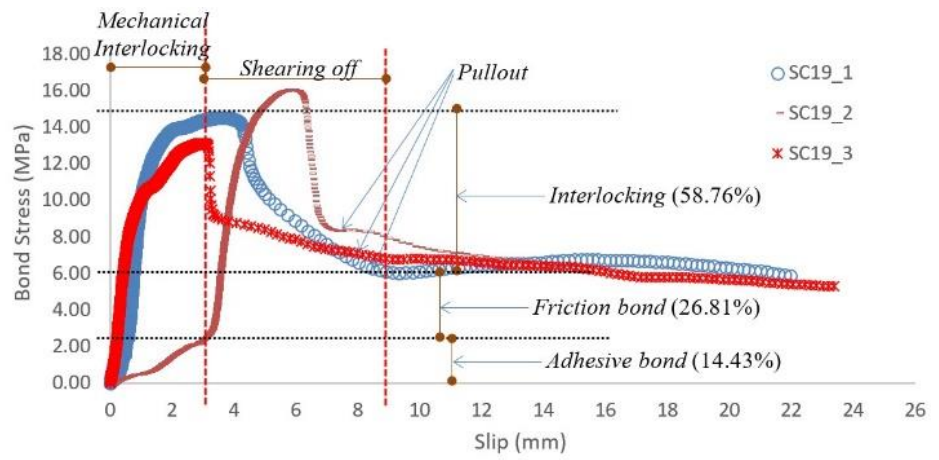

Fig. 14 - Bond Stress - Slip Graph of Steep Type Deformed Reinforcement Steel (SC19) 
Figure 14 shows the result of the pullout test for SC19 steep type reinforcement steel. The three specimens indicate similar patterns in the bond stress-slip curve [23]. The maximum bond stress reached is $14 \mathrm{MPa}$ with an approximately $3 \mathrm{~mm}$ slip. SC19_2 denotes higher bond stress, reaching $16 \mathrm{MPa}$ with a $6 \mathrm{~mm}$ slip. Bond mechanisms that occur in this specimen are adhesive bonds (14.43\%), friction bond (26.81\%), and interlocking (58.76\%). SC19_1, SC19_2, and SC19_3 specimens undergo pullout failure.

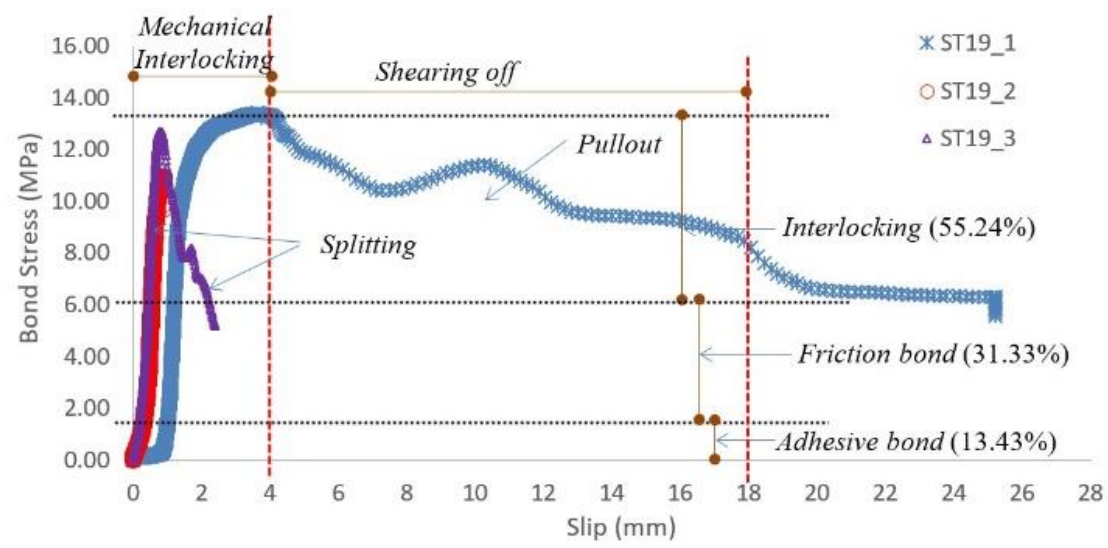

Fig. 15 - Bond Stress - Slip Graph of Fishbone Type Deformed Reinforcement Steel (ST19)

The result of the pullout test for ST16 fishbone type reinforcement steel is presented in Figure 15. The three specimens indicate different patterns in the bond stress-slip curve. ST19_2 and ST19_3 specimens show an almost identical pattern in the bond stress-slip curve, whereas ST19_1 has a different pattern with those two specimens. ST19_1 denotes the maximum bond stress, reaching more than $13 \mathrm{MPa}$ with a slip of approximately $3.5 \mathrm{~mm}$. ST19_2 and ST19_3 specimens indicate lower bond stress than the ST19_1 specimen. In this specimen, bond mechanisms are the adhesive bond, friction bond, and interlocking with a percentage of contribution of $13.43 \%, 31.33 \%$, and $55.24 \%$, respectively. Failure undergone by ST19_1 is pullout, whereas ST19_2 and ST19_3 are splitting.

\section{Comparison of bond strength between plain and deformed reinforcement steel}

Curves of bond stress-slip that occurs between concrete and surface of reinforcement steel, either plain or deformed, have been presented in Fig.ure7 to Figure 15. In general, the test results show that variations in diameter and reinforcement surface produce various abilities to withstand bond force. The slip that occurs shows different results in addition to the diverse magnitude of bond strength for each difference in diameter and reinforcement surface.

The bond strength of plain reinforcement steel is feeble, ranging from 2 to $4 \mathrm{MPa}$. However, the bond strength of deformed reinforcement steel is ranging from 16 to $20 \mathrm{MPa}$. This result is in line with previous research [2], [29], in which the bond strength of plain reinforcement steel is only about $18 \%$ of the bond strength of deformed reinforcement steel. The experiment result indicates that the ratio of bond strength of plain reinforcement steel compared to deformed reinforcement steel ranges between $15 \%$ and $18 \%$. The test result showing the bond strength of all specimens is illustrated in Figure 16. 


\section{$\left.\right|_{\substack{\text { CIVIL } \\ \text { ENGINEERING } \\ \text { JOURNAL }}}$}

Article no. 13

THE CIVIL ENGINEERING JOURNAL 1-2021

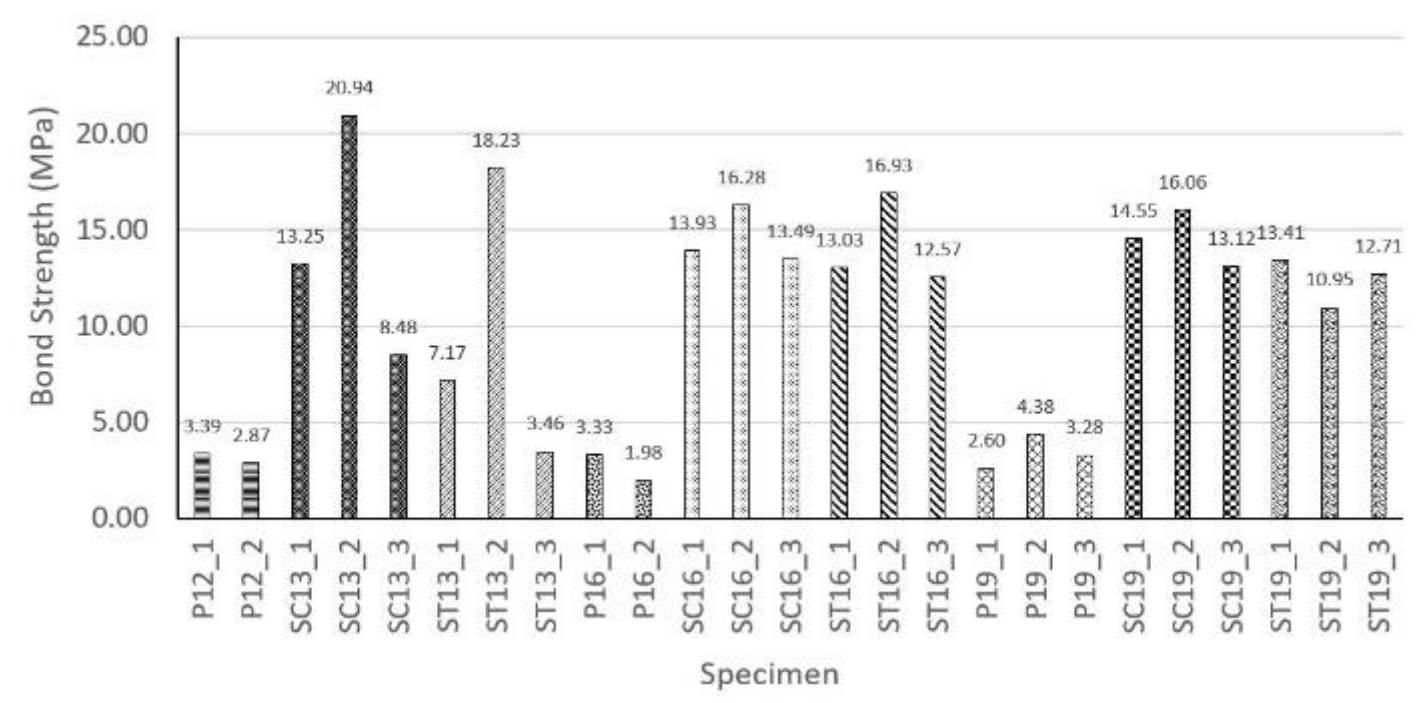

Fig. 16 - Maximum Bond Stress of Each Specimen

On the deformed bar, rib shape may affect its bond strength [5]. The parameter of the rib shape can be illustrated quantitatively in the form of the bond index. Based on research conducted by Metelli (2014) [21], a reinforcement that has a bond index ranging from 0.04 to 0.1 can increase bondability by up to $40 \%$. The steep type deformed reinforcement steel (SC) used in this experiment has a bond index value of $0.11-0.13$, while the fishbone type deformed reinforcement steel (ST) has a bond index value ranging between 0.14 and 0.16 . Therefore, the bond index values of both types are relatively identical. The result of an experiment on these two types of deformed reinforcement steel shows that their bond strength values are relatively similar. However, steep type deformed reinforcement steel tends to have a higher bond strength than fishbone type deformed reinforcement steel.

\section{The pattern of specimen failure}

The experiment results indicate that the occurring pattern of specimen failure is splitting and pullout, as presented in Table 3. The determination of this failure pattern is based on the shape of the bond stress-slip curve and visual observation of the specimen [6], [11], [22], [30]. The failure pattern that appears visually is only the specimen failure of fishbone deformed reinforcement steel with a diameter of $19 \mathrm{~mm}$ (ST19_2), as illustrated in Figure 17 and 18. 
Article no. 13

CIVIL

ENGINEERING

THE CIVIL ENGINEERING JOURNAL 1-2021 JOURNAL

Tab. 3 - The Pattern of Specimen Failure

\begin{tabular}{|c|c|c|c|c|c|c|c|c|c|}
\hline $\begin{array}{l}N \\
0\end{array}$ & $\begin{array}{l}\text { Specime } \\
\mathrm{n}\end{array}$ & \begin{tabular}{c|c} 
Averag & \\
e Bond & Adhes \\
Stress & i \\
(MPa) &
\end{tabular} & $\%$ & $\begin{array}{c}\text { Frictio } \\
n \\
(\mathrm{MPa})\end{array}$ & \multicolumn{2}{|c|}{$\%$} & $\begin{array}{l}\text { Inter- } \\
\text { locking }\end{array}$ & $\%$ & $\begin{array}{l}\text { Pattern } \\
\text { of } \\
\text { Failure }\end{array}$ \\
\hline 1 & $\mathrm{P} 12 \_1$ & 3.39 & \multirow[b]{2}{*}{0.40} & \multirow[b]{2}{*}{$11.79 \%$} & \multirow[b]{2}{*}{2.99} & \multirow{2}{*}{$\begin{array}{c}88.21 \\
\%\end{array}$} & \multirow[b]{2}{*}{ - } & \multirow[b]{2}{*}{ - } & Pullout \\
\hline 2 & P12_2 & 2.87 & & & & & & & $\begin{array}{c}\text { Splittin } \\
g\end{array}$ \\
\hline 3 & SC13_1 & 13.25 & \multirow{3}{*}{1.00} & \multirow{3}{*}{$7.55 \%$} & \multirow{3}{*}{7.50} & \multirow{3}{*}{$\begin{array}{c}49.07 \\
\%\end{array}$} & \multirow{3}{*}{5.75} & \multirow{3}{*}{$\begin{array}{c}43.38 \\
\%\end{array}$} & Pullout \\
\hline 4 & SC13_2 & 20.94 & & & & & & & $\begin{array}{c}\text { Splittin } \\
g\end{array}$ \\
\hline 5 & SC13_3 & 8.48 & & & & & & & Pullout \\
\hline 6 & ST13_1 & 7.17 & \multirow{3}{*}{1.00} & \multirow{3}{*}{$13.95 \%$} & \multirow{3}{*}{3.50} & \multirow{3}{*}{$\begin{array}{c}34.88 \\
\%\end{array}$} & \multirow{3}{*}{3.67} & \multirow{3}{*}{$\begin{array}{c}51.17 \\
\%\end{array}$} & Pullout \\
\hline 7 & ST13_2 & 18.23 & & & & & & & $\begin{array}{c}\text { Splittin } \\
g\end{array}$ \\
\hline 8 & ST13_3 & 3.46 & & & & & & & Pullout \\
\hline 9 & P16_1 & 3.33 & \multirow[b]{2}{*}{0.55} & \multirow[b]{2}{*}{$16.52 \%$} & \multirow[b]{2}{*}{2.78} & \multirow{2}{*}{$\begin{array}{c}83.48 \\
\%\end{array}$} & \multirow[b]{2}{*}{ - } & \multirow[b]{2}{*}{ - } & Pullout \\
\hline 10 & P16_2 & 1.98 & & & & & & & $\begin{array}{c}\text { Splittin } \\
g\end{array}$ \\
\hline 11 & SC16_1 & 13.93 & \multirow{3}{*}{1.00} & \multirow{3}{*}{$7.18 \%$} & \multirow{3}{*}{6.50} & \multirow{3}{*}{$\begin{array}{c}39.47 \\
\%\end{array}$} & \multirow{3}{*}{7.43} & & Pullout \\
\hline 12 & SC16_2 & 16.28 & & & & & & $\begin{array}{c}53.35 \\
\%\end{array}$ & $\begin{array}{c}\text { Splittin } \\
g\end{array}$ \\
\hline 13 & SC16_3 & 13.49 & & & & & & & Pullout \\
\hline 14 & ST16_1 & 13.03 & & & & & & & Pullout \\
\hline 15 & ST16_2 & 16.93 & 0.80 & $6.37 \%$ & 6.10 & $\begin{array}{c}42.17 \\
\%\end{array}$ & 6.47 & $\begin{array}{c}51.46 \\
\%\end{array}$ & $\begin{array}{c}\text { Splittin } \\
g\end{array}$ \\
\hline 16 & ST16_3 & 12.57 & & & & & & & Pullout \\
\hline 17 & P19_1 & 2.60 & & & & & & & Pullout \\
\hline 18 & P19_2 & 4.38 & 0.30 & $11.54 \%$ & 2.30 & $\begin{array}{c}88.46 \\
\%\end{array}$ & - & - & $\begin{array}{c}\text { Splittin } \\
g\end{array}$ \\
\hline 19 & P19_3 & 3.28 & & & & & & & Pullout \\
\hline 20 & SC19_1 & 14.55 & & & & & & & Pullout \\
\hline 21 & SC19_2 & 16.06 & 2.10 & $14.43 \%$ & 6.00 & $\begin{array}{c}26.81 \\
\%\end{array}$ & 8.55 & $\begin{array}{c}58.76 \\
\%\end{array}$ & Pullout \\
\hline 22 & SC19_3 & 13.12 & & & & & & & Pullout \\
\hline 23 & ST19_1 & 13.41 & & & & & & & Pullout \\
\hline 24 & ST19_2 & 10.95 & 1.80 & $13.43 \%$ & 6.00 & $\begin{array}{c}31.33 \\
\%\end{array}$ & 7.41 & $\begin{array}{c}55.24 \\
\%\end{array}$ & $\begin{array}{c}\text { Splittin } \\
g\end{array}$ \\
\hline 25 & ST19_3 & 12.71 & & & & & & & $\begin{array}{c}\text { Splittin } \\
g\end{array}$ \\
\hline
\end{tabular}




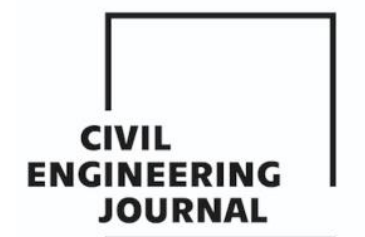

Article no. 13

THE CIVIL ENGINEERING JOURNAL 1-2021

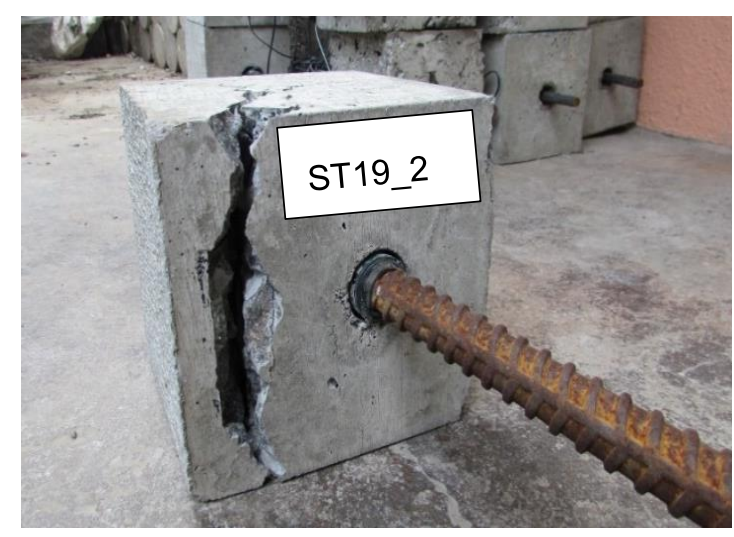

Fig. 17 - Splitting Failure of ST19_2 Specimen

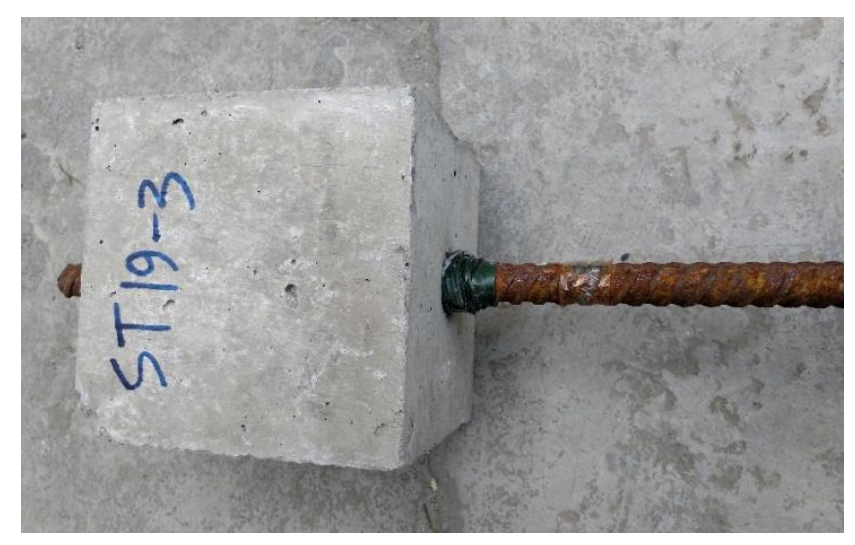

Fig. 18 - Splitting Failure of ST19_3 Specimen

Figure17 and 18 show specimens that undergo splitting failure. Figure 18 does not show a crack on specimen ST19_3; however, the bond stress-slip curve indicates that the failure undergone by the specimen is splitting (Fig. 15).

\section{CONCLUSION}

Based on the results of specimen testing, conclusions can be taken as follows:

1 The steep type deformed steel bar's bond stress is relatively identical with the fishbone type deformed steel bar. The maximum bond stress reached are ranging between 13 and $20 \mathrm{MPa}$. Those bond stress values are obtained from adhesion bond by $6 \%-14 \%$, friction bond by $27 \%$ $49 \%$, and interlocking by $43 \%-59 \%$.

2 The bond stress of the plain steel bar is relatively lower than the deformed steel bar. Compared to the deformed steel bar, the bond strength ratio of plain steel bar ranges between $15 \%$ and $18 \%$. The bond stress of plain reinforcement steel is obtained from adhesion bond by $11 \%$ $16 \%$ and friction bond by $83 \%-88 \%$. In plain steel bar, there is not interlocking force.

3 The bond index value (relative rib area) of steep type deformed reinforcement steel is almost identical with fishbone type deformed reinforcement steel, ranging from 0.11 to 0.16 . Thus, both types' bond stress values are almost similar as well because the variation is not too many different numbers.

4 The shape of the bond stress-slip graph determines the occurring failure pattern. There are two types of failure identified in this experiment, namely pullout and splitting failure. The failure of each specimen varies based on its diameter and rib shape. The splitting failure that can visually be observed is only the fishbone type deformed reinforcement steel specimen with a diameter of $19 \mathrm{~mm}$.

5 To prove the rib shape contribution needs to be an investigation with a rib reinforcement specimen that has a value in the rib area index that range-wide.

\section{ACKNOWLEDGEMENTS}

Thank you to The Research Center and Community Services Politeknik Negeri Jakarta, Civil Engineering Department Universitas Katolik Parahyangan, and all parties who have helped this research. 


\section{REFERENCES}

[1] M. Dehestani and S. S. Mousavi, "Modified steel bar model incorporating bond-slip effects for embedded element method," Constr. Build. Mater. J., vol. 81, no. April, pp. 284-290, 2015.

[2] G. Xing, C. Zhou, T. Wu, and B. Liu, "Experimental Study on Bond Behavior between Plain Reinforcing Bars and Concrete," Adv. Mater. Sci. Eng., vol. 2015, no. October, 2015.

[3] L. R. Feldman and F. M. Bartlett, "Bond strength variability in pullout specimens with plain reinforcement," ACI Struct. J., vol. 102, no. 6, pp. 860-867, 2005.

[4] SNI 2847:2019, Persyaratan Beton Struktural untuk Bangunan Gedung dan Penjelasan. Bandung: Badan Standardisasi Indonesia, 2019.

[5] H. A. O. Qing-duo, W. Yan-lei, Z. Zhi-chun, and O. U. Jin-ping, "Bond strength improvement of GFRP rebars with different rib geometries," J. Zhejiang Univ. Sci. A, vol. 8, no. 9, pp. 1356-1365, 2007.

[6] A. Rosyidah, I. K. Sucita, and F. Hidayat, "The Bond Strength of Glass Fiber Reinforced Polymer ( GFRP ) Reinforcement with Monolith Concrete," IJASEIT, vol. 8, no. 2, pp. 495-500, 2018.

[7] O. C. Choi and H. Choi, "Bearing Angle Model for Bond of Reinforcing Bars in Concrete," ACl Struct. J., vol. 114, no. 1, pp. 245-253, 2017.

[8] C. Bosco and F. Tondolo, "Bond Performance in Machined Reinforcing Bar for Reinforced Concrete," Appl. Mech. Mater., vol. 166-169, pp. 828-831, 2012.

[9] F. Xu, Z. M. Wu, J. J. Zheng, Y. Hu, and Q. Bin Li, "Bond behavior of plain round bars in concrete under complex lateral pressures," ACI Struct. J., vol. 111, no. 1, pp. 15-25, 2014.

[10] W.-J. Long, K. Khayat, G. Lemieux, S.-D. Hwang, and F. Xing, "Pullout Strength and Bond Behavior of Prestressing Strands in Prestressed Self-Consolidating Concrete," Materials (Basel)., vol. 7, no. 10, pp. 6930-6946, Oct. 2014.

[11] S. Hong and S. K. Park, "Uniaxial bond stress-slip relationship of reinforcing bars in concrete," Adv. Mater. Sci. Eng., vol. 2012, no. April, 2012.

[12] F. L. Li, K. F. Yu, X. X. Ding, and C. M. Li, "Bond Properties of Plain Steel Bar in Concrete with Machine-Made Sand," Appl. Mech. Mater., vol. 438-439, pp. 20-24, 2013.

[13] H. G. Kwak and J. K. Kim, "Implementation of bond-slip effect in analyses of RC frames under cyclic loads using layered section method," Eng. Struct., vol. 28, no. 12, pp. 1715-1727, 2006.

[14] H. G. Kwak and J. W. Hwang, "FE model to simulate bond-slip behavior in composite concrete beam bridges," Comput. Struct., vol. 88, no. 17-18, pp. 973-984, 2010.

[15] J.-Y. Lee et al., "Interfacial bond strength of glass fiber reinforced polymer bars in high-strength concrete," Composites Part B: Engineering, vol. 39, no. 2. pp. 258-270, 2008.

[16] L. R. Feldman and F. M. Bartlett, "Bond stresses along plain steel reinforcing bars in pullout specimens," ACl Struct. J., vol. 104, no. 6, pp. 685-692, 2007.

[17] H. Shima, L. L. Chou, and H. Okamura, "Micro and macro models for bond in reinforced concrete," Journal of the Faculty of Engineering, The Uinversity of Tokyo, vol. XXXIX, no. 2. pp. 133-194, 1987.

[18] M. Teresa, G. Barbosa, E. De Souza, and S. Filho, "Analysis of the Relative Rib Area of Reinforcing Bars Pull Out Tests 4 . Experimental Results and Discussion," Mater. Res., vol. 11, no. 4, pp. 453457, 2008.

[19] A. A. R. M.H.Harajli, B.S.Hamad, "Effect of Cofinement of Bond Strength between Steel Bars and Concrete," ACl Struct. J., vol. 101, no. September-October, pp. 595-603, 2004.

[20] M. H. Harajli, B. S. Hamad, and A. A. Rteil, "Effect of Confinement on Bond Strength between Steel Bars and Concrete," ACI Struct. J., vol. 101, no. 5, pp. 595-603, 2004.

[21] G. Metelli and G. A. Plizzari, "Influence of the relative rib area on bond behaviour," Mag. Concr. Res., vol. 66, no. 6, pp. 277-294, 2014.

[22] J. Zuo and D. Darwin, "Splice strength of conventional and high relative rib area bars in normal and high-strength concrete," ACI Struct. J., vol. 97, no. 4, pp. 630-641, 2000.

[23] C. W. Tang, "Uniaxial bond stress-slip behavior of reinforcing bars embedded in lightweight aggregate concrete," Struct. Eng. Mech., vol. 62, no. 5, pp. 651-661, 2017.

[24] M. Zhao, X. Zhang, K. Yan, T. Fei, and S. Zhao, "Bond Performance of Deformed Rebar in Steel Fiber Reinforced Lightweight-Aggregate Concrete Affected by Multi-Factors," Civ. Eng. J., vol. 18, no. 3, pp. 276-290, 2018.

[25] F. Wang, X. Wu, C. Guo, and W. Song, "Experimental Study on Bond Strength of Deformed Steel Bars in Recycled Glass Aggregate Concrete," KSCE J. Civ. Eng., vol. 24, no. 144, pp. 1-10, 2018.

[26] E. S. Dewi, Pengaruh Diameter Tulangan terhadap Kuat Lekat (Bond Strength) Beton Geopolimer. 2017. 
Article no. 13

CIVIL

ENGINEERING

THE CIVIL ENGINEERING JOURNAL 1-2021

[27] ASTM C234-91a (2000), Standard Test for Comparing Concrete on the Basis of Bond Developed with Reinforcing Steel. 2000.

[28] O. Leibovich, A. N. Dancygier, and D. Z. Yankelevsky, "An Innovative Experimental Procedure to Study Local Rebar-Concrete Bond by Direct Observations and Measurements," Exp. Mech., vol. 56, no. 12, pp. 673-682, 2016.

[29] D. Ertzibengoa, S. Matthys, and L. Taerwe, "Bond behaviour of flat stainless steel rebars in concrete," Mater. Struct., vol. 45, no. 11, pp. 1639-1653, 2012.

[30] W. M. Thomas, D. Ball, R. Fenn, and R. Challis, "The Effect of Geometry on Reinforcement Anchorage Performance and Integrity," in The Institute of Concrete Technology 43rd Annual Convention 2015 26th March 2015 Loughborough University, UK, 2015, no. April. 